\title{
PROFIL KELUARGA DISFUNGSIONAL PADA PENYANDANG MASALAH SOSIAL DI KOTA SEMARANG
}

\author{
Endang Sri Indrawati, Darosy Endah Hyoscyamina, Novi Qonitatin, Zaenal Abidin
}

Fakultas Psikologi Universitas Diponegoro

Jl. Prof. Sudharto SH, Tembalang, Semarang 50275

esi_iin@yahoo.com

\begin{abstract}
Dysfunctional family is a social problem that also caused other social problems. It is important to understand the basic character of family which has social problem in order to prevent and to solve social problems. This study aims to describe the profile of dysfunctional families which have social problems. The subject comprised 92 persons (70 men; 22 women; aged 15-79 years) who have social problems and stayed in the social centers, social rehabilitation centers, or slum areas of Semarang city. Data were collected using Dysfunctional Family Questionnaire and Risk-Parenting Scale and were analyzed using descriptive statistics. The results showed that the majority $(51.09 \%)$ of dysfunctional families which have social problems come from low economic status, low level of educational background $(21.74 \%$ fathers and $14.13 \%$ mothers finished junior high school of higher; the remaining subject went to elementary school or were illiterate); the majority of participants $(69.56 \%)$ have more than three siblings. Among parental inadequate behaviors, smoking behavior was considered to bring strongly negative impact to the family members.
\end{abstract}

Keywords: family profile, dysfunctional family, social problem

\begin{abstract}
Abstrak
Masalah sosial yang juga menjadi penyebab dari masalah sosial yang lain adalah keluarga disfungsional. Memahami karakter dasar keluarga tempat individu penyandang masalah sosial berasal adalah penting dalam upaya pencegahan dan penanggulangan masalah-masalah sosial. Penelitian ini bertujuan untuk mendapatkan profil disfungsionalitas keluarga dari penyandang masalah sosial. Penelitian ini merupakan penelitian survei. Responden penelitian ini adalah 92 orang (70 pria; 22 wanita; usia 15-79 tahun) penyandang masalah sosial yang berada di panti sosial, pusat rehabilitasi, maupun kantong-kantong kemiskinan di Kota Semarang. Data diperoleh dengan menggunakan Kuesioner Keluarga Disfungsional dan Skala Pengasuhan Berisiko. Data dianalisis menggunakan metode statistik deskriptif. Hasil penelitian menunjukkan bahwa pada keluarga penyandang masalah sosial, 51,09\% berasal dari keluarga dari tingkat ekonomi lemah; latar belakang pendidikan orang tua rendah; hanya 21,74\% ayah berpendidikan SMP ke atas dan hanya 14,13\% ibu berpendidikan SMP ke atas, sisanya berpendidikan SD atau buta huruf; dan memiliki banyak saudara; mayoritas $(69,56 \%)$ responden memiliki saudara lebih dari 3 orang. Diantara beberapa perilaku inadequate dari orang tua, perilaku merokok merupakan perilaku yang berdampak sangat negatif bagi anggota keluarganya.
\end{abstract}

Kata kunci: profil keluarga, keluarga disfungsional, masalah sosial

\section{PENDAHULUAN}

Hakikat pembangunan nasional adalah pembangunan manusia Indonesia seutuhnya dan pembangunan seluruh masyarakat Indonesia (UU No. 52 Tahun 2009). Pembangunan nasional mencakup semua dimensi dan aspek kehidupan termasuk perkembangan kependudukan dan pembangunan keluarga. Penduduk sebagai modal dasar dan faktor dominan pembangunan harus menjadi titik sentral dalam pembangunan berkelanjutan. Keberhasilan dalam mewujudkan pertumbuhan penduduk yang seimbang dan mengembangkan kualitas penduduk serta keluarga akan 
memperbaiki segala aspek dan dimensi pembangunan dan kehidupan masyarakat.

Salah satu upaya mewujudkan pertumbuhan penduduk dan keluarga berkualitas adalah dengan meningkatkan ketahanan dan kesejahteraan keluarga. Untuk mewujudkan ketahanan dan kesejahteraan keluarga, setiap warga negara berhak untuk membesarkan, memelihara, merawat, mendidik, mengarahkan, dan membimbing kehidupan anak-anak dalam keluarga termasuk kehidupan berkeluarga sampai dengan dewasa. Namun demikian, mewujudkan pembangunan nasional pada kenyataannya tidak pernah mudah, bahkan semakin sulit lantaran hambatan-hambatan yang semakin banyak dan berat. Hak untuk hidup dengan aman dan tenteram terusik oleh fakta tingginya tindak kriminal di tengah masyarakat. Jumlah penduduk yang menjadi korban mencapai 2,7 juta orang di mana 50,4\%-nya terjadi di pedesaan (BPS, 2010). Sementara itu, kemiskinan pun masih menjadi masalah yang tak kunjung usai. Pada tahun 2012, tercatat bahwa 29,13 juta penduduk Indonesia tergolong miskin (Bappenas, 2012).

Kemiskinan, sebagai masalah sosial yang paling serius, pun merundungi banyak keluarga di Indonesia. Permasalahan tersebut sangat mempengaruhi kehidupan di masyarakat, khususnya dinamika dalam keluarga, terutama mengenai bagaimana anak-anak dibesarkan dan perkembangan diri mereka di masa depan yang semakin jauh dari proses yang ideal dan berkualitas. Jika keluarga diyakini sebagai tempat pendidikan yang pertama dan utama bagi individu, maka keluarga yang disfungsional merupakan ancaman bagi perkembangan diri anggota-anggota di dalamnya pada khususnya dan bagi pembangunan Indonesia pada umumnya.

Parillo (2008) menyebutkan bahwa keluarga disfungsional mengacu pada "pola keluarga yang secara umum diasosiasikan dengan rendahnya tingkat kesehatan, kesejahteraan, kebahagiaan, dan pengaruhpengaruh positif jika dibandingkan dengan keluarga-keluarga lainya". Keluarga yang disfungsional tidak hanya pencetus masalah sosial, tetapi juga masalah sosial yang rumit. Keluarga disfungsional dapat mengakibatkan anggota di dalamnya mengalami penderitaan, kesakitan, dan kesulitan lantaran karakteristik dasar keluarga yang buruk. Keluarga disfungsional dapat menurunkan pola-pola kehidupan yang disfungsional kepada keturunan atau generasi penerus sehingga masalah sosial ini menjadi masalah yang berkelanjutan. Keluarga disfungsional dicirikan dengan adanya beberapa hal seperti kekerasan dalam rumah tangga (fisik, seksual, dan emosional), penggunaan obat-obatan dan alkohol yang kronis, kemiskinan, stres tinggi, konflik antar anggota, dan perceraian; yang semua itu menyakiti anak secara fisik maupun psikis.

Istilah keluarga disfungsional relatif dapat disetarakan dengan istilah "keluarga bermasalah sosial psikologis" yang digunakan Kementerian Sosial RI sebagai salah satu dari 22 penyandang masalah kesejahteraan sosial (Kementerian Sosial, 2009). Keluarga bermasalah sosial psikologis didefinisikan sebagai keluarga yang hubungan antar anggota keluarganya, terutama antara suami dan istri, kurang serasi sehingga tugas-tugas dan fungsi keluarga tidak dapat berjalan dengan wajar. Definisi tersebut tampak terlalu sempit karena sesungguhnya disfungsi keluarga memiliki spektrum indikator perilaku yang luas, tidak sebatas pada hubungan antar anggota keluarga yang tidak harmonis, yaitu 1.) adanya kekerasan emosional, fisik, atau seksual dan penelantaran anak dalam rumah tangga (child abuse) atau kekerasan terhadap pasangan (spouse abuse), yang melukai emosi dan fisik korban dan menjadikan keluarga sebagai lingkungan tempat tinggal 
yang mengancam bagi anak; 2) adanya penyalahgunaan narkoba dan alkohol yang kronis. Hal ini berdampak pada tingginya angka kekerasan dalam keluarga dan rendahnya kualitas hubungan orangtuaanak. Dampak selanjutnya pada anak adalah rendahnya prestasi akademik, penghargaan diri (self-esteem), dan indikator kesejahteraan psikologis lainnya; 3) adanya kemiskinan yang kronis, yang tidak memberikan individu kesempatan ekonomi yang memadai untuk meningkatkan kesejahteraan hidupnya, pendidikan yang cukup, dan harapan untuk memiliki masa depan yang lebih baik. Keluarga yang demikian mengalami prestasi belajar yang rendah, hampir tidak memiliki rencana untuk masa depan, melakukan tindak kriminal, menganggur, dan menggelandang.

Keluarga yang disfungsional memberikan banyak dampak buruk; dampak yang terburuk adalah jika individu yang semula menjadi korban, kemudian belajar mengembangkan pola hidup yang disfungsional yang diperoleh dari keluarganya dan selanjutnya membangun keluarga yang disfungsional.

Sebuah studi menunjukkan bahwa tidak semua orang yang hidup dalam lingkungan keluarga yang keras dan tidak sehat menjadi disfungsional atau tetap dapat hidup secara fungsional (Parillo, 2008). Orang-orang yang demikian adalah mereka yang berhasil memutus tali transmisi disfungsionalitas dari orangtua mereka; mereka umumnya memiliki beberapa karakter psikologis tertentu yang melindungi mereka dan meminimalkan efek negatif jangka panjang dari keluarga yang disfungsional, seperti: (1) kemampuan resiliensi; (2) tingginya tingkat kecerdasan/inteligensi; (3) lokus kontrol internal; (4) kemampuan untuk mengenali kesempatan-kesempatan untuk berubah; (5) kesadaran akan kemampuan memiliki kehidupan/masa depan yang lebih baik; dan (6) kesadaran akan dis- fungsionalitas yang dialami dan komitmen untuk berubah. Dari faktor eksternal, mereka memiliki orang-orang di luar keluarga yang memberikan dukungan sosial, seperti orang-orang yang dijadikan teladan (role model) untuk menjalani hidup yang baik.

Benton (1997) menyebutkan bahwa keluarga disfungsional merupakan kondisi apa saja yang mengganggu keberfungsian yang sehat dari sebuah keluarga. Setiap keluarga pasti pernah mengalami suatu kondisi sulit, apakah itu penyakit, kematian, atau masalah ekonomi, tetapi yang membedakan apakah keluarga itu sehat atau tidak adalah pada cara merespon masalah. Jika keluarga sehat kembali berfungsi normal setelah krisis berlalu, masalah dalam keluarga disfungsional cenderung menjadi kronis sehingga anak-anak tidak mendapatkan pemeliharaan dan pemenuhan kebutuhan yang seharusnya.

Dalam keluarga yang sehat, pertengkaran, kemarahan, salah paham, dan sakit hati (dengan kata lain ketidaksempurnaan), normal terjadi, tetapi tidak selalu. Anggota keluarga dapat mengekspresikan emosinya, saling bertanya dan memberi perhatian. Ada peraturan dan fleksibilitas sesuai kebutuhan dan situasi tertentu. Anak diperlakukan dengan penuh penghargaan, tidak merasa terancam akan kekerasan, dan diberi tanggung jawab sesuai dengan usianya. Sementara itu, orangtua bertanggung jawab atas pemeliharaan mereka dan tidak membiarkan anak melakukan tanggung jawab yang seharusnya mereka penuhi. Dalam keluarga yang sehat, berbuat salah adalah sesuatu yang wajar, dan tuntutan untuk sempurna disadari tidak realistis. Dalam keluarga disfungsional, kondisinya berkebalikan dengan hal-hal di atas.

Menurut Benton (1997), terdapat beberapa tipe keluarga disfungsional yaitu (1) underfunction parents, yaitu orangtua yang 
tidak menjalankan tugas dan kewajibannya sebagai orangtua dan membiarkan anakanaknya menghidupi diri mereka sendiri; (2) overfunction parents, yaitu orangtua yang berlebihan, terlalu keras dan kaku dalam memperlakukan anak agar memenuhi keinginan mereka, tidak membiarkan anak mereka berkembang untuk menjadi diri mereka sendiri; dan (3) orangtua yang tidak konsisten, atau dalam memperlakukan anak mereka melanggar batas dengan melakukan perbuatan yang tidak layak dilakukan oleh orangtua.

Forward (1989) mengistilahkan orangtua dalam keluarga yang disfungsional dengan "toxic parents" atau orangtua beracun. Semua orangtua tentu dipahami sebagai manusia, tidak dapat menjadi diri mereka yang baik dari waktu ke waktu. Mereka dapat berbuat salah dan tidak menyenangkan terhadap anak. Mereka terkadang marah, membentak, bertindak keras atau suka mengatur. Kebanyakan anak dapat menerima perlakuan yang demikian karena rasa cinta/sayang dan pemahaman yang mereka miliki pada orangtua. Namun, ada orangtua yang pola perilaku negatifnya konsisten dan mendominasi kehidupan anak. Mereka mencelakakan, menyakiti, menjahati anak mereka sendiri, menimbulkan luka fisik maupun psikis yang membuat anak trauma. Mereka inilah yang disebut toxic parents.

Toxic parent belajar cara mengasuh anak yang buruk dari orangtua mereka yang buruk ketika mengasuh mereka dan seterusnya anak-anak mereka pun berkemungkinan besar mengadopsi hal yang serupa. Secara psikologis, perlakuan buruk yang mereka terima menghancurkan penghargaan diri mereka dan mengarahkan mereka pada perilaku self-destructive. Mereka merasa tidak berharga, tidak dicintai, dan tidak adekuat. Perasaan ini dapat berlanjut sampai mereka dewasa, men-jadikan mereka sangat sulit untuk mewujudkan gambaran diri yang positif, kepercayaan diri, dan penilaian diri yang baik, dan mewarnai seluruh aspek kehidupannya.

Menurut Forward (1989), terdapat beberapa tipe toxic parents:

1. Orangtua yang tidak adekuat

Orangtua yang tidak adekuat adalah orangtua yang tidak melakukan praktik pengasuhan yang seharusnya, dengan tidak memenuhi kewajiban utamanya terhadap anak, seperti memenuhi kebutuhankebutuhan fisiknya, me-lindungi anak dari bahaya fisik dan emosional, memenuhi kebutuhan anak akan cinta, perhatian dan afeksi, serta mengajarkan anak petunjukpetunjuk moral dan etika. Orangtua yang tidak adekuat menimbulkan kerusakan justru bukan dari apa yang mereka lakukan, tetapi dari apa yang tidak mereka lakukan pada anak. Orangtua yang tidak adekuat membuat anak bertanggung jawab melakukan kewajiban orangtua mereka dan memenuhi kebutuhan diri mereka. Peranperan dalam keluarga menjadi menyimpang, membingungkan, dan tertukar. Anak yang menjadi korban menjadi orangtua bagi orangtua mereka, menjadi orangtua bagi diri mereka sendiri, tanpa ada sosok yang dapat diteladani dan dijadikan sumber belajar. Tanpa orangtua yang dapat dijadikan model peran, perkembangan identitas anak pun terganggu. Anak menjadi tulang punggung keluarga sebelum waktunya, tidak mengalami masa kanak-kanak yang semestinya, dan menyelesaikan persoalanpersoalan hidupnya seorang diri tanpa bimbingan sehingga berisiko terjerat caracara penyelesaian masalah yang tidak benar (seperti, menjadi pengguna narkoba) dan bergaul dengan orang-orang yang salah.

\section{Orangtua Pengontrol}

Orangtua pengontrol adalah orangtua yang mengatur anak dengan cara atau kondisi yang tidak tepat lagi bagi seorang anak 
untuk diatur dan menjadi penghambat bagi anak untuk berkembang menjadi dewasa sesuai usianya. Orangtua normal mengontrol anak mereka hanya sampai ketika anak mereka mampu mengontrol diri mereka sendiri. Pada umumnya, transisi ini terjadi ketika anak berusia remaja. Pada keluarga yang bermasalah, perpisahan yang sehat dengan orangtua ini tertunda bertahun-tahun lamanya atau bahkan tidak pernah terjadi. Orangtua yang memandang diri mereka baik-baik saja merasa tidak perlu lagi mengontrol anak mereka. Namun, kondisinya berbeda dengan orangtua yang memendam rasa kecewa pada kehidupan mereka dan merasa takut ditinggalkan. Mereka takut jika anak mereka dewasa dan meninggalkan mereka. Mereka membuat anak mereka menjadi tergantung pada diri mereka dengan menanamkan pola pikir bahwa diri mereka adalah segala-galanya sehingga selalu dibutuhkan atau menampilkan diri seakan-akan mereka orang yang tidak berdaya jika tanpa anak. Mereka ingin diri mereka diprioritaskan dan membuat anak terpaksa mengorbankan kehidupan mereka sendiri untuk memenuhi keinginan mereka. Hasilnya, anak tidak mampu membangun identitas dirinya sendiri, sulit memandang diri mereka sebagai seorang individu, tidak dapat membedakan kebutuhan diri sendiri dari orangtua mereka, dan merasa tidak berdaya.

\section{Orangtua yang alkoholik atau pengguna obat-obatan terlarang}

Keberadaan orangtua yang punya kebiasaan mengkonsumsi minuman keras atau obatobatan adalah hal yang menimbulkan rasa malu bagi anak atau anggota keluarga lainnya. Anak biasa takut jika aib keluarga ini terekspos kepada orang lain. Untuk mencegah agar orang lain tidak mengetahuinya, anak memilih waspada dengan tidak mau bersosialisasi sehingga ia menjadi pribadi yang terisolasi dan kesepian. Masalah yang muncul adalah orangtua yang alkoholik menjadi tidak mampu memenuhi kewajibannya sebagai orangtua dan melakukan kekerasan dalam keluarganya, terhadap pasangan atau anakanaknya.

\section{Orangtua pelaku kekerasan \\ a. Kekerasan verbal}

Mereka memiliki kebiasaan berkata-kata kasar atau buruk seperti memanggil anak dengan panggilan yang menghina, berkomentar yang merendahkan, dan memberikan kritik yang meremehkan anak. Kalimat-kalimat tersebut memberikan pesan negatif pada anak tentang diri mereka dan itu berdampak pada kesejahteraan psikologisnya di masa depan. Kebanyakan orangtua pasti pernah mengatakan hal-hal yang tidak menyenangkan pada anak. Namun, jika orangtua dalam berkata-kata seringkali menyerang anak, baik terhadap penampilan, inteligensi, kompetensi, atau nilai dirinya sebagai manusia, orangtua itu digolongkan telah melakukan kekerasan. Orangtua dapat melakukan kekerasan verbal secara terang-terangan, seperti dengan memanggil anak mereka "bodoh", "jelek", atau "tak berguna", atau berkata di hadapan anak bahwa mereka berharap tidak pernah punya anak, tanpa memikirkan perasaan anak mereka. Bagi pelaku yang tidak terang-terangan, mereka dapat menyerang anak dengan sindiran, sarkasme, nama-nama panggilan yang menghina, atau memoles itu semua dengan humor atau lelucon yang menyakitkan. Dampak jangka panjang dari orangtua yang demikian adalah perkembangan self-image anak yang buruk. Anak dapat meyakini dan menginternalisasikan perkataan orangtuanya tentang diri mereka, tidak memiliki kepercayaan diri, dan merasa rendah diri.

\section{b. Kekerasan Fisik}

Orangtua yang melakukan kekerasan fisik, menyebabkan luka-luka fisik pada tubuh anak, seperti memar, luka bakar, bilur-bilur, sayatan, retak/patah tulang yang disebabkan oleh tendangan, cubitan, gigitan, pukulan 
tangan, tikaman, ikatan, pukulan dengan alat, dan sebagainya. Namun, kekerasan fisik tidak sebatas itu. Apapun tindakannya, meskipun tidak berbekas, tetapi menyakiti anak, itu adalah kekerasan. Orangtua biasa melakukan kekerasan fisik sebagai cara cepat mendiamkan anak akibat dari ketidaksabaran lantaran kelelahan yang sangat, stres, kecemasan, atau ketidakbahagiaan. Mereka tidak dapat mengontrol impuls/ emosi negatif yang kuat dalam diri mereka dan tidak memikirkan konsekuensi dari perbuatan mereka. Jika ada kebutuhan yang tidak terpuaskan, mereka mengamuk dan bertindak brutal. Mereka terbiasa melakukan ini, terutama karena mereka dibesarkan dalam keluarga di mana kekerasan dan kekasaran biasa terjadi. Anak-anak mereka pun pada akhirnya terancam mengidentifikasikan diri dengan mereka karena memandang mereka yang melakukan kekerasan fisik begitu kuat dan kebal. Anak yang menjadi korban selanjutnya berharap memiliki kekuatan serupa agar dapat membela diri dan ketika dewasa, melanjutkan apa yang dilakukan orangtuanya ketika menghadapi stres.

\section{c. Kekerasan Seksual}

Terdapat orangtua yang melakukan kekerasan seksual pada anak (seperti melakukan perbuatan inses). Terkadang perbuatan itu mungkin tanpa kekerasan fisik, tetapi dengan tekanan-tekanan psikologis yang kuat. Mereka membombardir anak dengan ancamanancaman, seperti mengancam akan membunuh anak agar anak tetap bungkam. Anak umumnya tetap diam lantaran ketakutan yang sangat bahwa mereka akan lebih disakiti, atau kecemasan bahwa keluarganya akan menghadapi masalah, seperti perceraian orangtuanya, serta tekanan dan penghinaan publik. Ia merasa bertanggung jawab untuk menjaga keutuhannya dan ini menimbulkan beban emosi yang luar biasa karena rasa berdosa dan malu, rasa terteror, marah, sedih, bingung, kesepian, dan terisolasi. Anak yang menjadi korban kekerasan seksual dapat hidup dengan rasa bersalah, depresi, dan keinginan bunuh diri, mengalami masalah seksual, dan menjadi pengguna obat-obatan terlarang.

Hayatiningtyas (2011) mengkaji secara kualitatif dampak psikologis anak korban kekerasan fisik dan verbal dalam keluarga dan menemukan dampak umum yaitu ketidakberdayaan, kesedihan, dan rasa malu. Allen (2010) menyebutkan bahwa di Eropa dan Amerika, keluarga disfungsional dikaji secara ekslusif sebagai suatu fenomena psikologi-psikiatri; sebagai suatu masalah klinis-psikologis suatu keluarga yang mendorong munculnya gangguan mental dari individu korban keluarga tersebut.

Keluarga disfungsional adalah objek kajian psikoterapi sejak munculnya pandangan bahwa interaksi yang disfungsional dalam keluarga adalah penyebab berbagai simptom-simptom psikologis pada diri individu. Cara penanganan pun berubah, dari yang semula berorientasi pada penyembuhan medis terhadap simptom menjadi perbaikan situasi atau lingkungan yang menyebabkan kemunculan simptom, yaitu keluarga. Hal itulah yang mendorong munculnya terapi keluarga dan terapi lainnya yang berbasis keikutsertaan peran keluarga dalam upaya penyembuhan.

Pada penelitian medisnya, Felitti dkk (1998) mengkaji hubungan antara health risk behavior dan penyakit pada orang dewasa dengan pengalaman mengalami kekerasan emosional, fisik dan seksual, serta disfungsi keluarga selama mereka kanak-kanak. Ia menemukan adanya hubungan positif yang signifikan di antara variabel-variabel tersebut. Ia pun menyimpulkan bahwa pengalaman menderita kekerasan dalam rumah tangga dan hidup dalam keluarga yang disfungsional merupakan faktor risiko munculnya gangguan 
kesehatan, pola hidup tidak sehat (alkoholisme, penyalahgunaan zat, depresi, upaya-upaya bunuh diri, merokok, obesitas, dan sebagainya) dan penyakit (sakit jantung, kanker, sakit paru-paru kronis, patah tulang, dan gangguan liver), dan yang berpotensi menyebabkan kematian pada orang dewasa. Semakin berat masa kecil seseorang (semakin banyak kekerasan yang dialaminya), semakin banyak faktor risiko bagi kesehatannya di masa dewasanya.

Senada dengan penelitian tersebut di atas, Repetti, Taylor, \& Seeman (2002) juga menyimpulkan bahwa lingkungan keluarga pada masa kanak-kanak menunjukkan adanya hubungan yang vital untuk memahami kesehatan fisik dan mental seseorang sepanjang masa hidupnya. Keluarga yang berisiko, yang dicirikan dengan adanya konflik dan agresi, serta hubungan antar anggota yang dingin, tidak mendukung, dan penuh pengabaian, menyebabkan kerentanan pada diri anggotanya. Kerentanan ini mengganggu keberfungsian diri mereka secara psikososial (pengaturan emosi dan kompetensi sosial) dan sistem pengaturan tubuh dalam merespon stres, serta memunculkan pola hidup yang tidak sehat.

Penelitian-penelitian tentang keluarga disfungsional atau keluarga berisiko di atas memberikan banyak kontribusi bagi para praktisi kesehatan, terutama yang menggeluti bidang psikologi kesehatan. Keluarga yang disfungsional berperan sebagai faktor risiko penyakit jantung koroner (Loucks, Almeida, Taylor, \& Matthews, 2011), berhubungan positif dengan kemunculan simtom depresi (Taylor dkk, 2006), dan mempengaruhi fungsi metabolisme individu ketika dewasa (Lehman, Taylor, Kiefe, \& Seeman, 2005). Penelitian tersebut mendukung pandangan yang menyatakan bahwa "kesehatan yang baik dimulai sejak awal kehidupan", kesehatan yang buruk juga demikian.
Dalam keluarga yang sehat, anak-anak belajar bahwa mereka dapat mengandalkan lingkungan mereka untuk mendapatkan keamanan emosional dan fisik, serta kesejahteraan. Mereka pun belajar caranya memelihara kesehatan fisik dan psikis mereka sendiri, mandiri dari para pengasuhnya. Sebaliknya, dalam keluarga yang berisiko, dinamika yang sehat tersebut tidak terjadi dan justru men-ciptakan kerentanan dan konsekuensi-konsekuensi negatif pada perilaku dan kesehatan (Repetti, Taylor, \& Seeman, 2002).

Mengambil analogi dari konsep di atas, kemampuan seseorang untuk dapat berfungsi dengan baik sebagai anggota masyarakat dimulai sejak awal kehidupan dan sebaliknya, ketidakmampuan orang untuk berfungsi baik secara sosial juga demikian. Beberapa penelitian di Barat mendukung ini. Dodge dan Petit (2003) mengajukan model biopsikososial perkembangan masalah perilaku kronis pada remaja. Di samping adanya predisposisi biologis, konteks sosiokultural dan pengalaman-pengalaman masa awal kehidupan (terutama dengan keluarga) memainkan peran yang menentukan. Di level keluarga, status sosioekonomi ketika anak dilahirkan, menyangkut pendapatan, pekerjaan, dan tingkat pendidikan orangtua, merupakan faktor risiko paling kuat sekaligus paling konsisten bagi terbentuknya masalah perilaku. Kemiskinan adalah faktor utama, diikuti faktor perceraian orangtua, konflik antar orangtua, dan kelahiran dari orangtua remaja atau orangtua yang sendirian.

Di masa awal kehidupan, kualitas pengasuhan menjadi faktor yang menentukan (Dodge \& Petit, 2003). Masalah perilaku muncul dari keluarga yang: (1) memperlakukan anak secara kasar, mendisiplinkan anak secara tidak konsisten dan menggunakan kekerasan fisik; (2) kurang hangat antara orangtua dan anak; 
dan (3) minim bimbingan perilaku atau pendidikan, terutama ketrampilan sosial. Penemuan tersebut serupa dengan penelitian Indrawati (2011) tentang faktorfaktor yang mempengaruhi delinkuensi remaja. Diketahui bahwa keluarga memainkan peran yang sangat menentukan dan keluarga yang disfungsional dan gagal pengasuhan anak menjadi penyebab utama delinkuensi remaja. Beberapa perilaku bermasalah dalam keluarga yang penting dicatat, antara lain: (1) hubungan keluarga yang tidak harmonis: orangtua sering bertengkar; ayah melakukan kekerasan terhadap ibu; (2) dalam keluarga dengan ekonomi kuat, anak dimanjakan dan dibiasakan hidup enak; (3) ambiguitas prinsip pengasuhan anak antara ayah dan ibu: ayah keras dan otoriter, sedangkan ibu lemah; (4) kekerasan fisik untuk mendisiplinkan anak; dan (5) keluarga kurang religius.

Namun, sebelum mampu menyusun solusi dan mengimplementasikannya, perlu dipahami atau dikenali bentuk-bentuk pola pikir, sikap, dan perilaku bermasalah yang menjadikan seseorang penyandang masalah sosial. Mengetahui seberapa disfungsional keluarga yang bersangkutan adalah hal yang penting lantaran disfungsi keluarga tidak dapat dipahami secara dikotomis, melainkan sebagai suatu kontinum fungsional-disfungsional (Parillo, 2008).

Berdasarkan latar belakang di atas, dapat dirumuskan permasalahan sebagai berikut: Bagaimana profil keluarga para penyandang masalah sosial? Apa saja bentuk-bentuk perilaku bermasalah yang ada dalam keluarga individu penyandang masalah sosial?

\section{METODE}

Penelitian ini merupakan penelitian survei, yaitu suatu metode sistematis untuk mengumpulkan data dari sekelompok orang (dengan karakteristik tertentu) untuk menyusun deskripsi kuantitatif atas atribut yang dimiliki suatu populasi (Groves dkk, 2004).

Responden penelitian ini adalah penyandang masalah sosial yang ditampung di beberapa pusat rehabilitasi, panti sosial, atau yang tinggal di daerah-daerah miskin di Kota Semarang. Jumlah responden yang didapatkan adalah sebanyak 92 orang (70 laki-laki dan 22 perempuan) dengan rentang usia 15-79 tahun.

Dalam penelitian ini, keluarga disfungsional didefinisikan sebagai pola keluarga yang secara umum diasosiasikan dengan rendahnya tingkat kesehatan, kesejahteraan, kebahagiaan, dan pengaruh-pengaruh positif jika dibandingkan dengan keluargakeluarga lainya, ditandai dengan adanya beberapa hal, seperti penyalah-gunaan zat, gangguan mental, konflik orangtua, tindakan kriminal, dan kemis-kinan yang kronis. Praktik pengasuhan berisiko diartikan sebagai praktik pengasuhan anak yang buruk oleh orangtua, yang menimbulkan luka psikis maupun fisik pada diri anak yang berpotensial berlanjut sampai ia dewasa. Praktik pengasuhan ini ditandai dengan adanya kekerasan terhadap anak, tidak terpe-nuhinya hak-hak anak dari orang tuanya.

Data dikumpulkan dengan Kuesioner Keluarga Disfungsional dan Kuesioner Pengasuhan Berisiko yang disusun berdasarkan adaptasi dan penyempurnaan Adverse Childhood Experience (ACE) Questionnaire (Felitti, 1998) dan Risky Families (RF) Questionnaire (Taylor (2002).

\section{HASIL DAN PEMBAHASAN}

Profil keluarga responden dirangkum dan disajikan dalam Gambar 1-7 berikut ini. Sebagian besar (62\%) responden berada 
dalam usia produktif. Sebagian besar $(44,57 \%)$ berpendidikan SD atau sederajat dan memiliki tanggungan keluarga atau berstatus menikah $(57,61 \%)$. Dengan demikian, tampak bahwa penyandang masalah sosial sebagian besar merupakan kepala keluarga yang harus menghidupi keluarga, akan tetapi memiliki tingkat pendidikan rendah sehingga sulit mendapatkan pekerjaan yang layak.

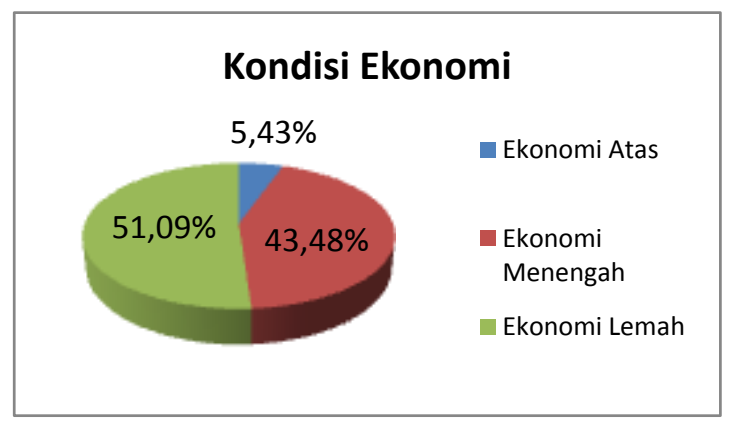

Gambar 1. Kondisi Ekonomi

Berdasarkan data keluarga asal, diketahui bahwa $51,09 \%$ responden berasal dari keluarga ekonomi lemah (Gambar 1). Pada Gambar 2 tampak bahwa mayoritas responden memiliki orang tua lengkap $(45,67 \%)$ dan tinggal bersama $(64,13 \%)$, serta memiliki tempat tinggal yang memadai $(59,78 \%)$. Dari penjelasan responden secara kualitatif, yang dimaksudkan dengan tempat tinggal memadai adalah tempat tinggal yang memenuhi fungsi sebagai tempat berteduh tanpa memandang sisi permanen, atau kelengkapan fasilitas rumah.

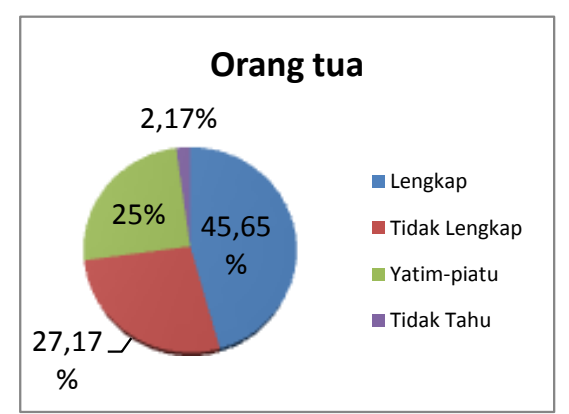

Gambar 2. Keberadaan Orang Tua
Pola keluarga besar juga dimiliki oleh responden dengan data yang menunjukkan sebanyak $41,3 \%$ responden memiliki saudara yang berjumlah 3 sampai dengan 5 orang (Gambar 3).

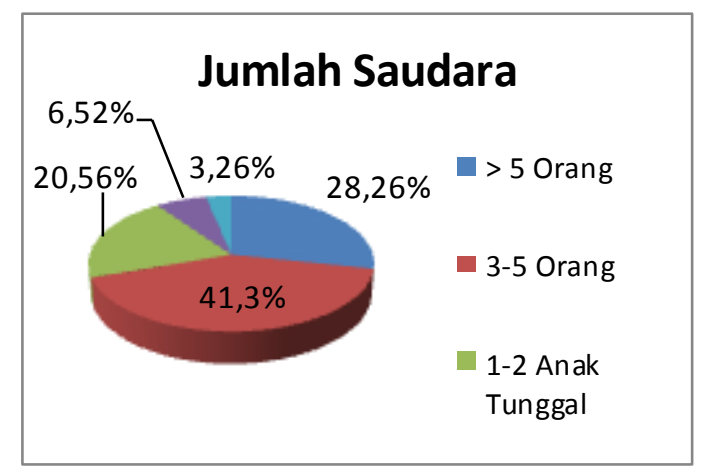

Gambar 3. Jumlah Saudara

Kondisi keluarga besar yang tinggal bersama, walaupun memiliki tempat tinggal yang dianggap memadai (Gambar 4), dengan tingkat ekonomi yang lemah membuat mereka mengalami kesulitan dalam memenuhi kebutuhan hidup.

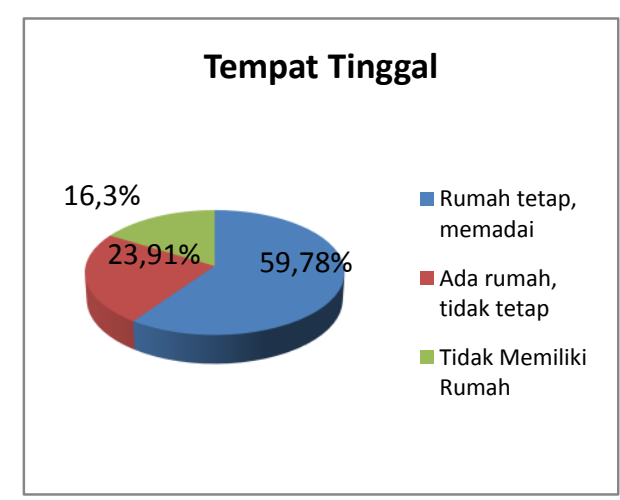

Gambar 4. Tempat Tinggal

Dari data demografis ditemukan bahwa responden selain memiliki tingkat pendidikan rendah, mereka juga berasal dari keluarga dengan tingkat pendidikan kedua orangtua yang rendah pula. Hal ini diperlihatkan pada Gambar 5 dan Gambar 6 dimana mayoritas tingkat pendidikan tertinggi ayah adalah SD $(35,87 \%)$; dan ibu dengan pendidikan SD $(35,87 \%)$, tidak bersekolah $(21,74 \%)$ atau tidak diketahui 
bersekolah atau tidak $(28,26 \%)$.

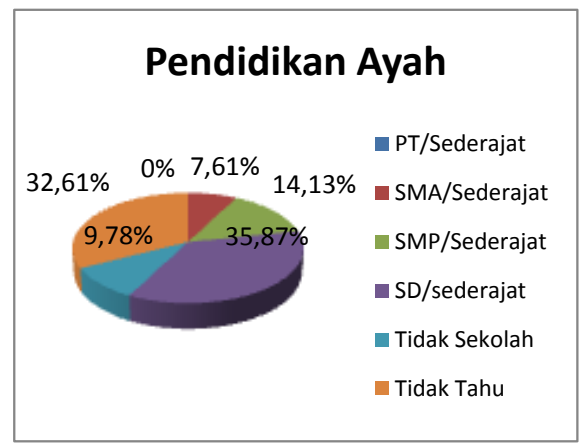

Gambar 5. Tingkat pendidikan Ayah

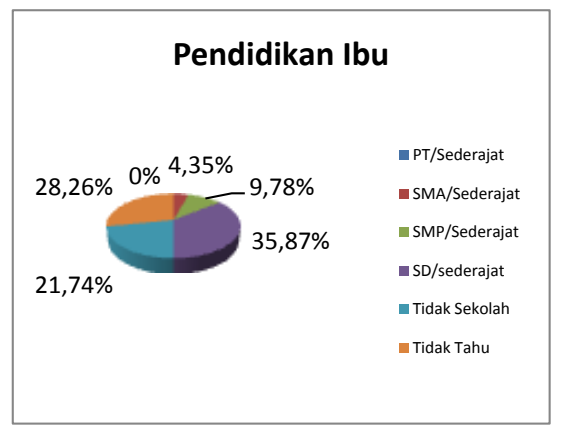

Gambar 6. Tingkat pendidikan Ibu

Tingkat pendidikan yang rendah dari orangtua tampak berdampak pada tingkat pendidikan responden yang juga sebagian besar berada adalah SD $(44,57 \%)$ atau SMP $(30,43 \%)$. Faktor ekonomi lemah menjadi alasan dan kendala responden tidak melanjutkan sekolah ke jenjang yang lebih tinggi.

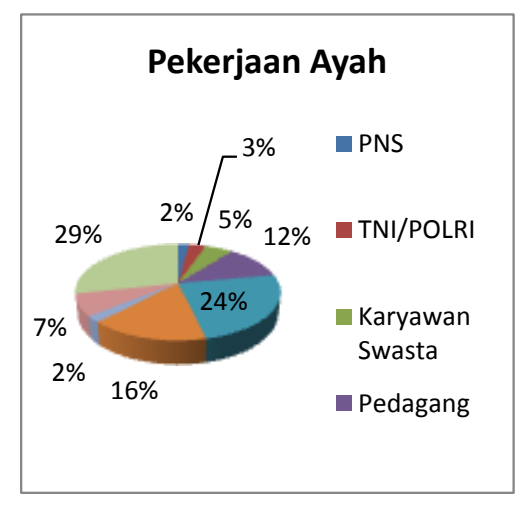

Gambar 7. Pekerjaan Ayah
Dari sisi pekerjaan orangtua, sebagian besar adalah petani (ayah 25\%; ibu 23,91\%). Bahkan mayoritas ibu adalah ibu rumah tangga $(23,91 \%)$.

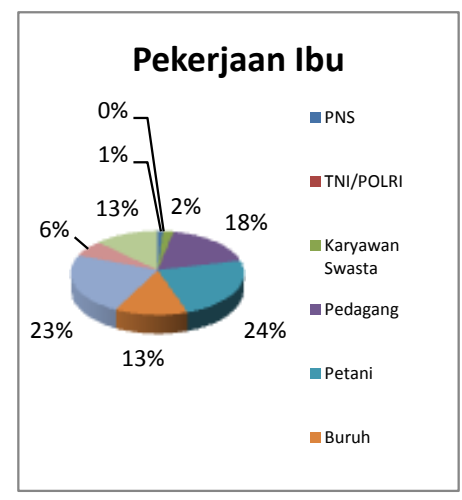

Gambar 8. Pekerjaan Ibu

Hal ini mengindikasikan bahwa keluarga asal responden sebagian besar bukanlah dari kota besar yang memiliki lahan pertanian, sehingga dapat disimpulkan bahwa mereka melakukan urbanisasi ke kota dengan maksud mengubah kehidupan yang lebih baik. Akan tetapi, dengan kesiapan yang kurang, seperti pendidikan, kompetensi mapupun pengalaman yang kurang memadai, kehidupan tersebut tidak dapat diraih, justru mereka terjebak menjadi penyandang masalah sosial. Dari hasil penelitian dapat diketahui bahwa selain responden yang memang menjadi warga di Balai Rehabilitasi Sosial, responden yang lain memiliki pekerjaan sebagai pengamen, pengemis dan pemulung.

Kemiskinan yang terjadi pada responden, menyebabkan kesempatan untuk lebih baik di kemudian hari menjadi terhambat karena faktor ekonomi. Terutama terjadi pada upaya peningkatan tingkat pendidikan yang akhirnya juga menjadi terkendala. Hal ini menyebabkan mereka pada akhirnya ikut menjadi miskin. Kondisi ini sesuai pendapat Parillo (2008), yaitu adanya kemiskinan yang kronis menyebabkan tidak terpenuhinya kesempatan ekonomi yang memadai untuk meningkatkan kesejah- 
teraan hidupnya, pendidikan yang cukup, dan harapan untuk memiliki masa depan yang lebih baik.

Bila melihat kondisi responden dari perilaku pengasuhan berisiko yang tampak dari pola interaksi keluarga, maka data yang didapatkan menunjukkan bahwa interaksi keluarga yang terjadi pada keluarga asal cenderung positif. Perilaku kasar dan kekerasan cenderung rendah dengan $32,26 \%$ sangat rendah dalam skor hipotetik dan $45,16 \%$ dalam sebaran skor empirik. Sedangkan perilaku positif seperti memberi pengarahan nilai agama dan kasih sayang menunjukkan skor tinggi dengan $34,41 \%$ pada sebaran skor hipotetik dan 35,48\% pada sebaran empirik. Data ini menunjukkan bahwa pola interaksi dalam keluarga yang positif tidak menjadi salah satu sebab perilaku bermasalah yang berujung pada keluarga disfungsional, meskipun tidak dapat dipungkiri kemungkinan jawaban normatif yang dapat dimunculkan responden. Akan tetapi, seperti yang diungkapkan oleh Dahlan (2004), dalam perubahan sosial budaya, keluarga pun akan mengalami perubahan yang beragam. Ada keluarga yang semakin kokoh dalam menerapkan fungsinya, tetapi ada juga keluarga yang mengalami keretakan atau ketidakharmonisan (disfungsional). Dalam hal ini, keluarga asal yang menunjukkan interaksi yang memadai ternyata belum menjamin untuk munculnya fungsi keluarga yang baik di masa depan.

Perilaku tidak adekuat yang dilakukan keluarga juga tidak menunjukkan bahwa responden berasal dari keluarga yang memberikan kondisi negatif. Sebaran persentase menunjukkan mayoritas responden tidak memiliki keluarga yang berperilaku tidak adekuat, kecuali dalam beberapa kasus, terdapat perilaku perokok berat (sebesar 70,65\%). Hanya saja ada beberapa prosentase yang cukup terlihat lebih dibandingkan kondisi pada keluarga asal. Seperti masalah terbelit hutang $(36,96 \%)$, ada anggota keluarga yang pemabuk $(34,78)$, keluarga bercerai $(32,61 \%)$, dan minggat $(32,61 \%)$. Dari data tersebut dapat dilihat bahwa masalah keuangan juga menjadi salah satu sumber munculnya masalah di kemudian hari.

Ketidakharmonisan di dalam keluarga dalam bentuk perceraian ataupun kabur dari rumah memberikan situasi yang tidak nyaman dalam keluarga. Beberapa hal ini dapat memberikan kondisioning yang tidak disadari bagi responden untuk membentuk menjadi penyandang masalah sosial. Seperti yang diungkapkan oleh Parillo (2008), penyalahgunaan narkoba dan alkohol berdampak pada tingginya kekerasan dalam keluarga dan rendahnya kualitas hubungan orangtua dengan anak. Dalam penelitian ini dapat dilihat bahwa kondisi anggota keluarga yang perokok berat ataupun pemabuk juga melatarbelakangi respoden menjadi penyandang masalah sosial.

Dari data yang diperoleh, tampak bahwa keluarga asal responden tidak menunjukkan perilaku-perilaku yang jelas merujuk pada masalah-masalah sosial. Akan tetapi, tingkat pendidikan dan kondisi ekonomi yang rendah dengan tanggungan keluarga yang besar dapat menjadi sumber terjadinya disfungsi keluarga. Harapan untuk mendapatkan penghidupan yang lebih baik ketika bekerja di kota, tanpa didukung kompetensi dan persiapan yang memadai justru menjadi permasalahan yang lebih besar bagi kehidupan mereka.

\section{KESIMPULAN}

Kondisi keluarga yang disfungsional berkaitan dengan faktor sosioekonomi, pendidikan, keadaan keluarga, dan perilaku inadekuat dari orang tua. Berdasarkan hasil penelitian yang dilakukan, dapat 
digambarkan bahwa mayoritas responden berasal dari keluarga ekonomi rendah (51,09\%), latar belakang pendidikan orantua rendah (di bawah SMP),jumlah anak dalam keluarga lebih dari $3(41,3 \%)$, serta orangtua adalah perokok $(70,65 \%)$. Penelitian awal ini bersifat deskriptif dan menggambarkan profil keluarga para penyandang masalah sosial. Oleh karena itu diperlukan kajian mendalam tentang keluarga disfungsional pada penelitian selanjutnya.

\section{DAFTAR PUSTAKA}

Allen, D. M. (2010). How dysfunctional families spur mental disorders: A balanced approach to resolve problems and reconcile relationships. Santa Barbara, CA: Praeger.

Badan Pusat Statistik. (2010). Statistik kriminal 2007-2009. Jakarta: Badan Pusat Statistik.

Bappenas. (2012). Kemiskinan di Indonesia dan penanggulangannya. Diakses dari: http://www.bappenas.go.id/berita-dansiaran-pers/kegiatanutama/kemiskinandi-indonesia-dan-penanggulangannya/

Benton, S. A. (1997). Dysfunctional families: Recognizing and overcoming their effects. Kansas State University Counseling Service. Diakses dari: http://www.kstate.edu/counseling/topic s/relationships/dysfunc.html

Cresswell, J. W. (2012). Educational research: Planning, conducting, and evaluating quantitative and qualitative research. Boston: Pearson.

Dahlan, D. (2004). Psikologi perkembangan anak dan remaja. Bandung: Remaja Rosdakarya.
Dodge, K. A. \& Pettit, G. S. (2003). A biopsychosocial model of the development of chronic conduct problems in adolescence. Developmental Psychology,39(2): 349-371.

Felitti, V. J., Anda, R. F., Nordenberg, D., Williamson, D. F., Spitz, A. M., Edwards, V., Koss, M. P., \& Marks, J. S. (1998). Relationship of childhood abuse and household dysfunction to many of the leading causes of death in adults: The Adverse Childhood Experiences (ACE) Study. American Journal of Preventive Medicine, 14(4), 245-258.

Fletcher, G. J. O \& Clark, M. S. (2003). Blackwell handbook of social psychology: Interpersonal Processes. Cornwall: Blackwell Publishers Ltd.

Forward, S. (1989). Toxic parents: Overcoming their hurtful legacy and reclaiming your life. New York: Bantam Books.

Groves, R. M., Fowler, F. J., Couper, M. P., Lepkowski, J. M., Singer, E., \& Tourangeau, R. (2004). Survey methodology. Hoboken, NJ: John Willey \& Sons.

Hayatiningtyas, O. (2011). Dampak psikologis anak korban kekerasan dalam keluarga. (Skripsi). Tidak diterbitkan. Universitas Katolik Soegijapranata, Semarang.

Indrawati, E. S. (2011). Faktor-faktor yang Mempengaruhi delikuensi remaja: Studi kualitatif deskriptif pada warga binaan Lapas anak Kutoarjo. Laporan Penelitian. Semarang: Fakultas Psikologi Universitas Diponegoro. 
Irawan, P. (2007). Penelitian kualitatitif dan kuantitatif untuk ilmu-ilmu sosial. Jakarta: Self Press.

Kementerian Koordinator Kesejahteraan Rakyat (Menkokesra). (2009). Data Penyandang Masalah Kesejahteraan Sosial (PMKS) Tahun 2009. Diunduh dari: $\quad$ http://data.menkokesra.go.id/ sites/default/files/Data PMKS_2009.xls

Kementerian Sosial. (2009). Data penyandang masalah kesejahteraan sosial (PMKS) potensi dan kesejahteraan sosial (PSKS) Tahun 2009. Diakses dari: http://database.depsos.go.id/modules.p hp?name=Pmks2009\&opsi=pmks2009$\underline{2}$.

Lehman, B. J., Taylor, S. E., Kiefe, C. I., \& Seeman, T. E. (2005). Relation of childhood socioeconomic status and family environment to adult metabolic functioning in the CARDIA study. Psychosomatic Medicine, 67, 846-854.

Loucks, E. B., Almeida, N. D., Taylor, S. E., \& Matthews, K. A. (2011). Childhood family psychosocial environment and coronary heart disease risk. Psychosomatic Medicine, 73, 563571.
Maria, U. (2007). Peran persepsi keharmonisan keluarga dan konsep diri terhadap kecenderungan kenakalan remaja. (Tesis). Tidak diterbitkan. Universitas Gadjah Mada, Yogyakarta.

Parillo, V. N. (2008). Encyclopedia of Social Problems. Thousand Oaks: SAGE Publication.

Repetti, R. L., Taylor, S. E., \& Seeman, T. E. (2002). Risky families: Family social environments and the mental and physical health of offspring. Psychological Bulletin,128(2), 330366.

Taylor, S. E., Way, B. M., Welch, W. T., Hilmert, C. J., Lehman, B. J., \& Eisenberger, N. I. (2006). Early family environment, current adversity, the serotonin transporter polymorphism, and depressive symptomatology. Biological Psychiatry, 60, 671-676.

UU RI No. 52 Tahun 2009 tentang Perkembangan Kependudukan dan Pembangunan Keluarga 